\title{
Appraisal of Parking Problems and Traffic Management Measures in Central Business District in Lagos, Nigeria
}

\author{
Samson Babatunde Osoba ${ }^{1}$ \\ ${ }^{1}$ Department of Transport Management Technology, Federal University of Technology, Minna, Ibadan \\ Correspondence: Samson Babatunde Osoba, Department of Transport Management Technology, Federal \\ University of Technology, Minna, Ibadan. E-mail: monitunde@yahoo.com
}

Received: April 6, 2012 Accepted: July 3, 2012 Online Published: July 26, 2012

doi:10.5539/jsd.v5n8p105

URL: http://dx.doi.org/10.5539/jsd.v5n8p105

\begin{abstract}
Transport problems are very common in the Central Business District of Nigeria Cities as a result of the growing concentration of population, rapid urbanization and economic activities of certain point of the world. Edward Ulman observed that transport is applied to move people, goods or service in order to enable two place to interact in which there must be a specific demand and supply. The attended cost and dependability of transport service and infrastructures have enabled an increasing number of people to seek economic, social and education opportunities that urban areas ideally provided. But contrarily, Central Business District metropolitan cities have grown to the point where threaten to strangle the transportation that made them possible. In view of the above, research work examine, the problem associated with Parking and traffic Management problem within Ikeja Local Government Area Central Business District. The method used for data collection were mainly questionnaire administration; secondary data extracted from documented information relevant to the research work; formal and informal interview and data analysis, technique and interpretation. Relevant literatures on the research topic were reviewed.

Findings in this research work revealed that parking problems and Traffic Management which leads to time delays and traffic congestion are as a result of inadequate parking space, traffic signs/signals, human factor indiscipline act and development of illegal stall at car park.

Recommendation was made for Parking Management, Parking design standard, parking control; traffic management for both vehicular and pedestrian, Land-use and Land development; enforcement of edict and bye-laws by statutory agencies.
\end{abstract}

Keywords: parking, traffic, transport, congestion, vehicular and metropolitan

\section{Introduction}

The growth in population of the world today, towns and cities have grown up around their public transport system. The increasing population and expanding urban centers has been accompanied by increasing car ownership rate and increasing demand for movement for various purposes. Regardless of income or social status, the condition under which we all travel have become more and more difficult and for some absolutely intolerable. Demand for transport and travel intensity tend to increased sharply with the growing size of a city and town especially when the city center or major activity areas increase corresponding in terms of both area and employment. In an urban setting such as Lagos which is the fastest growing urban center in Nigeria, where the population is almost 15 million people, it initially served as the capital of Nigeria until December 1991 when the Federal Capital was moved to Abuja, there is the need to critically preview what facilities are available to the private car owners and Mini-Bus Operators that form a larger percentage of road users in the Central Business District (CBD), who daily activities constitute traffic congestion which resulted to delay in travel time. This could have prompted the choice of this topic.

Transportation is an important factor in the transformation of a nation's economy. The development of all transport mode in Lagos served as a useful catalyst in the economic development of the city coupled with commercial and administrative activities in Ikeja has a result of the seat of government situated at Ikeja. The commercial areas are high traffic generating Land-use areas, growing with the increasing population. Road traffic congestion from time immemorial constituted one of the major problems of a high level of urbanization, 
and to reduce the traffic congestion to barest minimum, the government (both state and local) have embark on a lot of parking and traffic management programmes such as Parks Monitoring Unit, Lagos State Traffic Management Authority (LASTMA), both under the Lagos State Ministry of Transportation and also Parks and Markets Monitoring Unit under Local Government Council e.g. Ikeja.

There exist myriads of parking and traffic problems in the Central Business District (Opebi/Allen and Alusa) and also series of corrective measures have been proposed and implemented to minimized the traffic and parking dilemma all with negligible positive results.

In addition, the rise in the cost of land in the city center is gradually eroding away the possibility of having convention and adequate parking space in business district.

It has become apparent to seek for more information about parking problem and traffic congestion situation of the city (Central Business District) and the existing measures imposed at correcting them.

This project intends to find appropriate solution to the following fundamental question such as what are the causes of parking problem? What are the causes of traffic congestion? How adequate are the existing transport facilities in meeting the growing population. How efficient are the agencies responsible for development control? Are there adequate set-backs of building from the carriageway (Road)? What are the measures proffered to correct the inadequacies?

Vehicular traffic movement and availability parking space (garage bus laybyes) becomes more paramount when critically viewed from the level of huge investment that has been pumped to the road sector by successive Federal, State and Local Governments. This is borne out of its suitability for fast movement of vehicles as a result of free flow of traffic and the increase in road capacity due to provision of parks and laybys.

The road transport operation is a circulatory system that must be a continuous process and any infringement at any point along the line will affect the whole system and hinders the effectiveness.

The problem of parking and traffic management in terms of vehicular free flow remain stagnant or rather snail movement particular in metropolitan Lagos most especially business districts. Therefore, investigation and research work on the chosen topic will necessary in order to find an appropriate solution as a means to an end but not an end itself.

\section{Study Area and Methodology}

\subsection{Study Area}

Alausa/Agidingbi and Allen/Opebi Business District are important part of Lagos metropolis; they are situated in Ikeja Local Government Area of Lagos State. Lagos metropolis refers to that whole area covering what is known as the city of Lagos and its immediate sub-urban environ.

Lagos State was created on May 27, 1967 as one of the twelve states that emerged from the former regions that constitute the Federal Republic of Nigeria. Its geographical location together with the socio-political status as a former federal capital with international linkage points (Routes) and hinterlands contributed to its development both economically and physically.

It has a total landmass of about 3577 square kilometers with $22 \%$ of the figure being water bodies. It has an estimated population of 5.72 million for the year 199191991 Census) and further projected to reach 17.58 million by year 2020. While the population density of Lagos has been put at 1,308 people per square kilometers (National Population Commission), compared with 85 persons $/ \mathrm{km}^{2}$ for Nigeria.

There is a great different in-terms of settlements and commercial activities between the sparsely centres in the urban sectors. Several reasons have been given for the unprecedented urbanization process. Oyesiku (1996), in his study, asserted that an average of $63.8 \%$ of total allocation was proposed for road, $14.2 \%$ on rail, $8.0 \%$ on air and $14.0 \%$ on water transport.

Lagos metropolis occupations about $37 \%$ of the Lagos State area as at 1990 and contains about $95 \%$ of the State's population (Dar-Al-Hardasah, 1995) Dar-Al-hardasah Report (1998) confirms that an average of 44 people migrate to Lagos every hour.

The state has 20 local government areas as recognized by 1999 amended constitution of FRN but proposed for 57 local government areas which is yet to be consider by the National Assembly. Transport facilities in the state feature all the existing transport modes such as Road, Water, Rail and Air. Despite the high allocation of investment (Fund) on road infrastructure, the mobility and accessibility needs of the people are far from being solved as traffic congestion makes intra-city journey around the metropolis and the state at Large cumbersome. 
The Land Use pattern in Lagos and its environs is made up of residential, commercial, industrial, institutional and recreational land uses. Others are forested water bodies such as creeks and Lagoons, dry and wetlands.

The indigenous people of the state are the Awori and Egun in Ikeja and Badagry areas respectively and the Ijebus in Ikorodu and Epe. The first settles of Lagos Island were an admixture of Ilajes, Aworis, Eko and Benin.

\subsection{Transport Network}

Lagos is blessed with all the transportation modes, i.e. overland (Road and Rail), Water, Air and Pipelines. Roads in Lagos are of three categoeis. Trunk A called Federal Roads (highways), Trunk B - States Roads and Trunk C - Local Government roads.

A major ingredient of rapid socio-economic development is a good quality road network. And also is the adequate maintenance of such roads and drain. Some important routes in Lagos Metropolis are as follows. Lagos-Ibadan Expressway, third mainland bridge Obafemi Awolowo Way, Kudirat Abiola Way Ojota Garaga etc. Despite these features, such problems as parking and traffic congetion, inadequate public transport and inadeaute maintenance are still prevalent in the State.

\subsection{Methodology}

The primary data were obtained from well-structured questionnaires and personal interview, as well as physical observation of the areas covered by road networks under focus.

The questionnaires were administered to drivers, corporate bodies within CBD agencies responsible for parks and traffic management, such as Lagos State Ministry of Transportation, Lagos State Traffic Management Authority and other agencies that has anything to do in the study area, most especially those relating to Parks and traffic Management. Information collected includes their effort, policy guidelines, management strategies, operations, organization set-up and staff strength in meeting the demand for parking space in the study areas.

A set of questionnaire were administered on the drives (motorists) making use of the parking facilities in other to obtain some information about origin and destination of trips, frequency of trip, purpose of trip as well as income and age distribution.

The respondents were randomly selected in such a way that every individual in the area has an equal chance of being included in the survey. This is because the time chosen for the collection of information range from $7.30 \mathrm{am}$ to $6.30 \mathrm{pm}$. Within which the traffic would be at its peak. Traffic enumeration point were identified along the roads within the boundary of the central business district, with two enumerators at each census points, one conducted the on-street parking survey while the other recorded traffic count along a particular direction of the road.

Survey parking accumulation and turnover. Four enumerators were placed at each designated parking space whether on-street (e.g. Laybys) and off-street parking spaces. One of the enumerators recorded the rate of parking while the other two enumerators interviewed the motorist using the parking space while the fourth collects information of the parking facilities characteristics. Parking Survey and Traffic Survey enumeration sheet were used to obtain the parking volume and traffic flow data.

The secondary data were extracted from documented information related to research on the cause, effect and solutions to parking problem and traffic congestion in Lagos Metropolis.

\section{Theoretical and Conceptual Underpinning}

\subsection{Urban Car Parking Model}

This model is of significance important both at the local and at the strategic level of planning. Parking policy and supply play a major role in traffic management systems in dense urban areas. The amount and the location of parking affect, in particular, the level of service and congestion on access roads. Parking behaviour is characterized by complex dynamic relationship between multi-dimensional demands, performance and supply quantities. The most commonly used parking models related parking demand to the scale of a single land use (ITE, 1985; TANSW, 1985). The general approach has been extended (Le \& Young, 1989) to take into account mixed land uses. The distinguishing features of the models that should be used to investigate parking policy is that they should accurately represent these relationships.

\subsection{Traffic Assignment Models}

This model assigns vehicles to the traffic and parking network given an original destination matrix. Austin (1973) presented two processes for the allocation of parkers to parking stations in the Central Business District (CBD). Firstly using trip generating model to determine the number of trips destined to particular zones in the CBD. 
Parkers were then allocated to parking stations depending on the cost of parking and walking distance. The allocation of trips was in proportion to the composition cost associated with each origin and parking lot destination pair. The capacity of the parking system was included by using an interactive procedure.

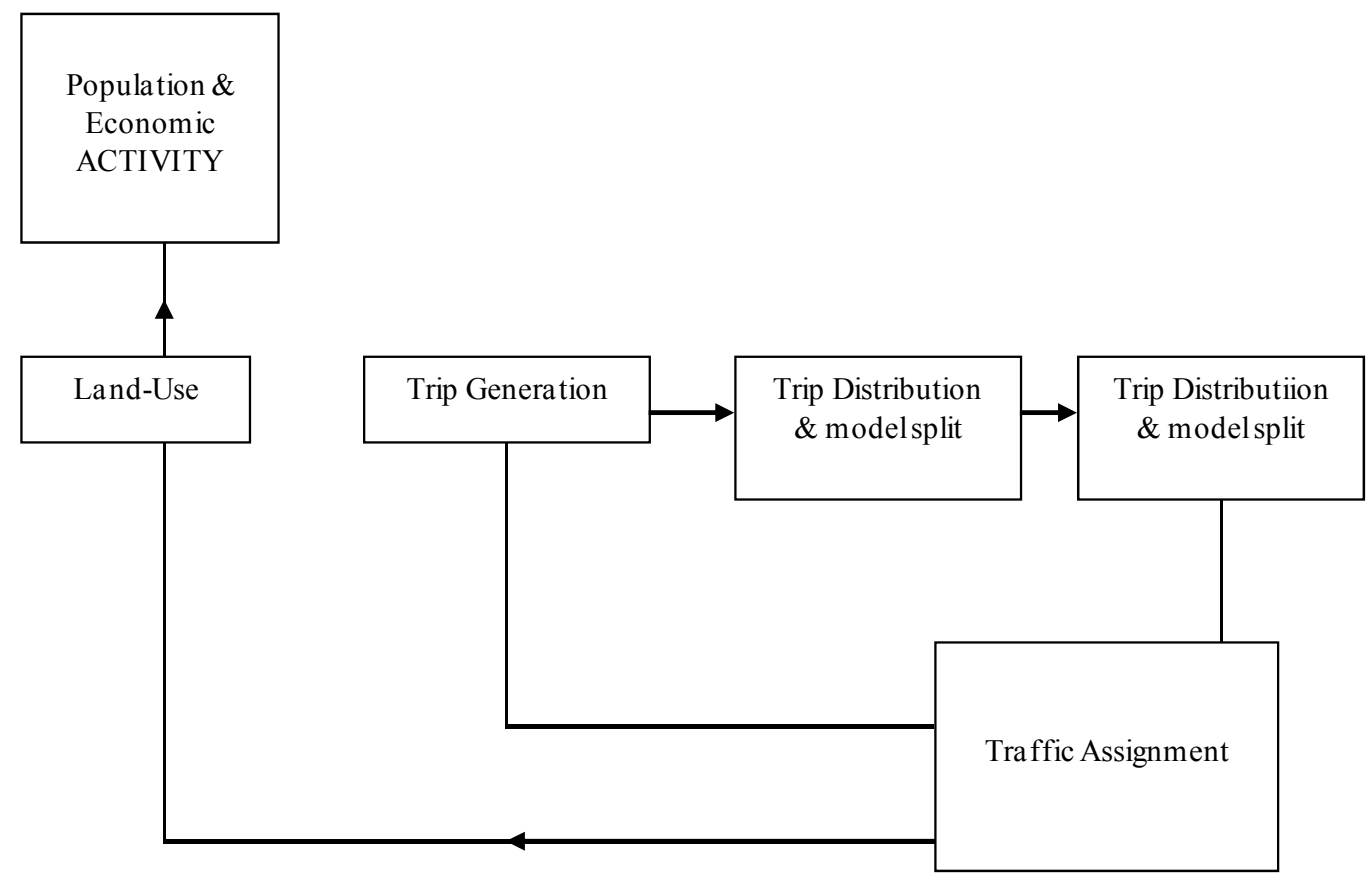

Figure 1. Modelling Process in Transportation Planning

Source: Transportation Engineering Radnor, Norman and Paul (pp 277).

The Gur-beinborn model was part of a larger system used to analyse the impact of integrated transport systems management strategies in city centers. Included in the procedures were calculations of parking impedance for each parking location in the area, including illegal parking. The model included the amount of time spend looking for a parking space as an increasing function of the utilization level of the parking area. With this relationship, it was possible to describe and analyse the parking process within the framework or user-optimized equilibrium assignment.

In this model parking has been considered as daily system, arrival rate patterns vary throughout the day. Gut and Beimborn described the application of the model to a high-density section of Haifa, Israel. In the test case the sensitivity of parking behaviour was examined as it varied with the value of walk time, parking cost, parking fines, enforcement policies and level of travel demand.

\subsection{Traffic Flow Theory}

Wattle Worth (1976), there have been many significant development in traffic flow theory. Some of these developments have led to very useful relationship while some application has not been all that useful.

He further said that probably, the most useful result of traffic flow theory is the development of the relationship among the macroscopic variables of traffic stream flow (flow rate, speed and density). Traffic Engineering uses the flow theory for the development of the level of services concept.

However, there has been some criticism of the traffic flow theory work regard the lag between the theoretical development and the application of some portion of the flow theory work. The traffic flow theories have largely looked into the basic relationship (why things happen). The traffic Engineers owe them a lot, for these theorists are physicists and mathematicians.

The fundamental characteristics of traffic stream flow are:
a. Flow
b. Speed
c. Density 
Wattle Worth (1976) defined rate (q) as the rate at which vehicles pass a point on a roadway. It is expressed in vehicles per how (veh/hr).

$$
q=\frac{v e h}{H r}=v p h\left(v / h r v h^{4}\right)
$$

The volume $(\mathrm{Q})$ is also defined as the number of vehicles observed in a given time $(\mathrm{T})$ volume is based on an actual count and expressed as vehicle. For example $Q=5000$ veh in $10 \mathrm{~min} .=30,000 \mathrm{vph}$.

\section{Results and Discussion}

The mixed paradigm of land use and vehicular traffic flow in Ikeja Central Business district has a lot of implication on the vehicular traffic flow paradigm of the area. In view of the foregoing the research work was carried out. This enables the transportation Engineers and traffic planners to know the behavior of traffic planners to know the behavior of traffic flow in the area and eventually plan for it. The data were collected through traffic enumeration exercise and administered questionnaire at some selected points on roads carrying traffic through within the business districts are analyze here.

\subsection{Traffic Volume Analysis}

The Standard P. C. U. used are:

Private Cars, Tax, Light goods Vehicles 1.00

Medium/Heavy goods $\quad 2.00$

Buses, Coaches, Trailer, lorries $\quad 3.0$

Motor - Cycle $\quad 0.75$

Pedal - Cycles $\quad 0.33$

Table 1. Hourly traffic flow (passenger car unit) in Allen a venue

\begin{tabular}{|c|c|c|}
\hline Time & Week Days (PCU) & Peak Period/Off-Peak Period \\
\hline $7.3-8.30$ & 1363 & \\
\hline $8.30-9.30$ & 1337 & \\
\hline $9.30-10.30$ & 1255 & 1320 \\
\hline $10.30-11.30$ & 1170 & \\
\hline $11.30-12.1 .30$ & 1083 & \\
\hline $12.30-12.30$ & 950 & \\
\hline $1.30-2.30$ & 932 & 1048 \\
\hline $2.30-3.20$ & 1105 & \\
\hline $3.30-4.30$ & 1279 & \\
\hline $4.30-5.30$ & 1342 & 1320 \\
\hline $5.30-6.30$ & 1338 & \\
\hline Total & 13,159 & \\
\hline
\end{tabular}

Source: Author's Survey. 
Table 2. Hourly Traffic flow (passenger car unit) in Opebi Road

\begin{tabular}{|c|c|c|}
\hline Time & Week Days (PCU) & Peak Period/Off-Peak Period \\
\hline $7.3-8.30$ & 1143 & 7 \\
\hline $8.30-9.30$ & 1112 & \\
\hline $9.30-10.30$ & 1015 & 1090 \\
\hline $10.30-11.30$ & 1006 & \\
\hline $11.30-12.1 .30$ & 978 & \\
\hline $12.30-12.30$ & 975 & \\
\hline $1.30-2.30$ & 1043 & 990 \\
\hline $2.30-3.20$ & 950 & \\
\hline $3.30-4.30$ & 1012 & 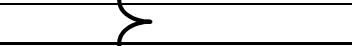 \\
\hline $4.30-5.30$ & 1118 & 1090 \\
\hline $5.30-6.30$ & 1141 & \\
\hline Total & 11,493 & \\
\hline
\end{tabular}

Source: Author's Survey.

Table 3. Hourly traffic flow (passenger car unit) in IPM Avenue

\begin{tabular}{|c|c|c|}
\hline Time & Week Days (PCU) & Peak Period/Off-Peak Period \\
\hline $7.3-8.30$ & 1025 & ) \\
\hline $8.30-9.30$ & 1024 & \\
\hline $9.30-10.30$ & 1025 & 1058 \\
\hline $10.30-11.30$ & 963 & \\
\hline $11.30-12.1 .30$ & 951 & \\
\hline $12.30-12.30$ & 902 & \rangle \\
\hline $1.30-2.30$ & 980 & 952 \\
\hline $2.30-3.20$ & 966 & \\
\hline $3.30-4.30$ & 1004 & \\
\hline $4.30-5.30$ & 1064 & 1058 \\
\hline $5.30-6.30$ & 1105 & $\rho$ \\
\hline Total & 11,109 & \\
\hline
\end{tabular}

Source: Author's Survey.

Table 4. Hourly traffic flow (passenger car unit) Hakeem Balogun street

\begin{tabular}{|c|c|c|}
\hline Time & Week Days (PCU) & Peak Period/Off-Peak Period \\
\hline $7.3-8.30$ & 864 & 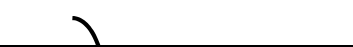 \\
\hline $8.30-9.30$ & 752 & \\
\hline $9.30-10.30$ & 732 & 777 \\
\hline $10.30-11.30$ & 740 & \\
\hline $11.30-12.1 .30$ & 721 & \\
\hline $12.30-12.30$ & 640 & $>$ \\
\hline $1.30-2.30$ & 672 & 737 \\
\hline $2.30-3.20$ & 644 & \\
\hline $3.30-4.30$ & 834 & \\
\hline $4.30-5.30$ & 845 & 687 \\
\hline $5.30-6.30$ & 861 & 1 \\
\hline Total & & \\
\hline
\end{tabular}

Source: Author's Survey. 
The record in Table 4 reveal that the traffic volume measured in P.C.U. in Allen business areas in higher during the peak period with an average of 1.320 was obtained as against 1,048 P.C.U. for off-peak period. The peak hours traffic flow indicate that the traffic intensity is high in the early morning when journey to work, school and business are undertaken while the evening peak period shows that most people are returning home, recreational etc.

\subsection{Parking Characteristics}

Parking surveys are intended to supply all information required for suitable parking and terminal facilities effectively. Parking in both the business districts during the survey were under taken through the two basic parking methods, namely: On-Street and Off-Street parking facilities. On-Street Parking: Is the adequate space for vehicles at the side of the road. Terminal - Is a parking space whether at the earth or off-street in a lot, garage, shopping center or private driveway. Bus-stop - Is a parking space provided for motorists along the road way in the central business districts and also at designated place.

\subsubsection{Availability of Parking Facilities}

Table 5 shows that larger percentage of the respondents in the Study are involved in off-street parking, which are very near to their destination and close to the carriageway. In assessing the adequacy of the parking facilities in Ikeja Business district, $76.5 \%$ of the respondents believe that they are fairly adequate and adequate respectively. On-Street Parking is being practiced in both business districts. The private vehicles engaged in parking along the Stretch of the roads in the areas. The Ikeja Local Government also designated some spaces within the business districts for On-Street parking. However, the spaces are provided for the use of private cars only. These facilities are not laid out into lots and thus give rise to chaotic traffic situation and result to traffic congestion.

Table 5. Parking facilities in Opebi-Allen Cbd

\begin{tabular}{ccc}
\hline Kind of Parking facility & No of Respondents & Percentage (\%) \\
\hline Private Car Park & 18 & 18 \\
Public Car Park & 2 & 2 \\
On-Street Parking & 38 & 38 \\
Off-Street Parking & 42 & 42 \\
Total & 100 & 100 \\
\hline
\end{tabular}

Source: Author's Survey.

\subsubsection{USAGE of Parking Facilities}

Table 6 revealed that $65 \%$ of the respondents uses the parking facilities because its nearness to their destination. While $17 \%$ and $18 \%$ of the respondents uses the facilities due to lack of parking space at their destination and to avoid traffic congestion respectively.

Table 6. Purpose of usage or parking facilities in central business districts

\begin{tabular}{ccc}
\hline Purpose & No of Respondents & Percentage (\%) \\
\hline Nearness to my destination & 65 & 65 \\
Lack of Parking Space at my & 17 & 17 \\
Destination & 15 & 15 \\
Avoid traffic Congestion & 3 & 3 \\
No response & $\mathbf{1 0 0}$ & $\mathbf{1 0 0}$ \\
Total &
\end{tabular}

Source: Author's Survey. 


\section{Analysis of Motorists and Commuters in Ikeja Central Business Districts}

Table 7 indicate that $78 \%$ of the people population in the daylight come from outside the study area. Thus, traffic congestion may arise in the morning and evening peak period went raveling from Original to destination i.e. Home to office and office to home.

Table 7. Survey of respondents residential area availability of parking facilities

\begin{tabular}{ccc}
\hline Location & No of Respondents & Percentage (\%) \\
\hline Within Ikeja L.G.A. & 22 & 22 \\
Outside Ikeja L.G.A. & 78 & 78 \\
Total & $\mathbf{1 0 0}$ & $\mathbf{1 0 0}$ \\
\hline
\end{tabular}

Source: Author's Survey.

Table 8 revealed that majority of the respondents travel to the CBD through privately owned vehicle and public transport. This implied that more vehicles are plying the roads, which can be linked to the traffic congestion in the study area.

Table 8. Mode of travel

\begin{tabular}{ccc}
\hline Mode of Travel & No of Respondents & Percentage (\%) \\
\hline Private Vehicle & 51 & 51 \\
Public Transport & 45 & 45 \\
Waling & 4 & 4 \\
Total & $\mathbf{1 0 0}$ & $\mathbf{1 0 0}$
\end{tabular}

Source: Author's Survey.

Table 9 revealed that a total of $78 \%$ of the Central Business District, Mostly for business and employment purpose. Consequent to the Land Use in the Study Area, which are predominantly commercial.

Table 9. Purpose of Visit to Ikeja Central Business District

\begin{tabular}{ccc}
\hline Purpose of Visit & No of Respondents & Percentage (\%) \\
\hline Employment & 32 & 32 \\
Business & 46 & 46 \\
Shopping & 12 & 12 \\
Recreation & 6 & 6 \\
Others (Specify) & 4 & 4 \\
Total & $\mathbf{1 0 0}$ & $\mathbf{1 0 0}$ \\
\hline
\end{tabular}

Source: Author's Survey.

Table 10 revealed that most of the respondents spend between 30 minutes and 1 hour in traffic delay. The delay caused by traffic congestion has a negative impact on business transaction, consequent to man-hour loss to traffic delay. 
Table 10. Traffic delay on visit to Ikeja Central Business District

\begin{tabular}{ccc}
\hline Traffic Delay & No of Respondents & Percentage (\%) \\
\hline Less than 30 minutes & 46 & 46 \\
Between 30 Minutes - 1hour & 48 & 48 \\
Above 1 hour & 6 & 6 \\
Total & $\mathbf{1 0 0}$ & $\mathbf{1 0 0}$ \\
\hline
\end{tabular}

Source: Author's Survey.

In light of the foregoing, the respondents proffered suggestion on ways to improve traffic situation in the study area.

They are:

a. Provision of more public parking spaces some distance away from the roads (Off-Street Parking).

b. Effective traffic Control Measures

c. Effective Development Control Measures

d. Enlightenment Campaign on the use of road for motorists.

The various data collected within the study area (IKeja Central Business Districts) has dearly marked it out as a commercial Land us, with increase in day light population and decrease in night population, and also with its attendant of parking problems and coupled with traffic congestion brought about by inadequate parking facility and inefficient traffic management system.

\section{Recommendation and Conclusion}

In light of the findings of this research work, the following recommendations are suggested to reduce and possible eradicate the problems of parking and traffic congestion confronting the study areas. All Local Planning Authorities should specify and enforced the provision of parking space in conjunction with new building. And also old building in CBD's should be refurbished to accommodate adequate parking space. Education and enlightenment programme are basic tools for achieving effective traffic management control. In Lagos most motorist are not conversant with the traffic rule and regulation. Dis-obedience to traffic signs/signals resulted traffic congestion in most of our roads. However, the laudable educative programmes embark upon by Government and Private Organization as change the attitude of motorists on our highway. Therefore, the programme should be well funded and expand the scope.

Location of Parking Facilities: The space for parking vehicles is a basic requirement in commercial areas. Parking facilities must be provided to help the area perform its prime function - that of accessible, attractive and profitable market place. Therefore parking facilities should be located at easily accessible off-street point and convenient to the motorist ultimate destination. In Opebi-Allen CBD, Off-Street parking should be provided along Opebi-Oregun road. These are parking facilities that are located completely out of the roadway. Good access streets should serve the facility and it is desirable to locate facility such that no exit or entrance is within a distance of at least $50 \mathrm{~m}$ from intersection. This is in conformity with road design concept. On-Street parking can only solve a part of parking problem of major cities if properly manage. In Lagos the problem of management does not encourage on-street parking. For a suitable parking and satisfactory answer to traffic congestion in Lagos, particularly the studied area, various types of off-street parking facilities become unavoidable. The types of off-street facilities to be considered are:

a. Surface Car Parks

b. Multi Storey Car Parks

c. Roof Parks

d. Under-ground Car-ground Car-parks

These facilities are costly to provided and maintain. However, the service render is so enormous to traffic management. Obviously, the prime consideration should be the nearness to the place of usage by the prospective customs. That is, it should be close to major parking generator. Examples of such location are shopping district, office building and commercial establishment etc. These properly located and developed on a piece of vacant land or surrounding an office complex or shopping mail, are very popular with the motorist. Great care is needed 
in their design and Operation. The overall aesthetics of the area should receive due attention. A stall of $2.5 \mathrm{~m} \mathrm{x}$ $0.5 \mathrm{~m}$ is probably adequate for Nigeria conditions. Among the suggested parking methods includemulti-story car park, roof parks, underground car parks, peripheral parking schemes, park and walk, park and ride, kiss and ride and provision of bus-bays. These facilities have become common and popular in many cities. Examples of such cities are Lagos Island, Victoria Island etc. One of the alternative when land is costly is to provide multi-story Car parks.

Another very popular method of solving the parking problems in many cities is to park the vehicle on roof tops. Access ramps provide the necessary access to the roof. It is also costly to provide and maintain. In addition to the ramps, extra cost is involved in designing the roof tops and the structural elements for the parking load. The greatest advantages of under ground car parks is the least intrusion they cause to the aesthetics of a place. These parks can be built in the basement of any multi-storey building. Since the work involves, large quantity of excavation, construction of retaining walls, ventilation and lighting this constitute the high cost of providing the facilities. Such facilities are also found in Lagos Island (Bookshop house).

Since the studies area is worst hit by the parking problem, it is necessary to think in terms of providing parking facilities at the periphery of the town and induce the motorist to park there and travel to the business district by some other mode. The following are devised to secure the desired objectives:
a. Park and Walk
b. Park and Ride
c. Kiss and Ride
d. Provision of Bus Bays

Under this scheme the motorists are induced to park at the outskirts of the town and walk down to the business district. The inducement is in the form of lower parking charges at the periphery that at the town center. This scheme provides for peripheral parking facilities and public transport ride to the destinations in the town center. This is an attractive scheme and has been tried with success in many towns. During the second republic, it was tried in Lagos at Mile 2 (ferry Jetty) for commuters traveling to Lagos Island CBD. However, the programme lacks consistency.

This scheme derives its name from the good-bye kiss of a wife dropping her husband in the car in the morning near a bus stop from where the husband goes to work in a bus. The reverse operation takes place in the evening. Adequate space for parking of cars near the bus stops where the husbands can be dropped off or their arrivals awaited is an essential prerequisite for the success for the scheme. Properly designed bus-bay recessed into the street facilitates loading and unloading of passengers without the vehicles blocking the stream of traffic on the carriageway. The study also suggested the following:

(1) Enforcement of Traffic Rules and Regulations by Disciplined Law Enforcement Agent

Indiscriminate use of road facilities is very common amongst motorist and very often, the uncoordinated manner through which the road system is used creates further crisis. Thus, the need for an effective means of enforcement. To this end, Police and the traffic Management Authorities are the frontlines in traffic laws. They should be mandated to enforce the rules and regulations binding the vehicular traffic operations without any fear or favour in order to mate out penalties and punishment to defaulters.

(2) Introduction of Information Technology

The use of computers and other information technological tools like communication gadgets and radar for traffic monitoring are highly relevant for solving complex issues relating to parking problem and traffic management.

\subsection{Conclusion}

It has been noticed that parking problems and traffic congestion are apparent in commercial area as a result of the land use pattern. The commercial land use has a high vehicular and pedestrian traffic generating capacity. Demand for parking spaces and other facilities are high. The inability of the existing situation to cope with the demand has later led to parking problem and traffic congestion. The recommendations put forward have been in light of findings from the field survey. Finally, if all the recommendation mentioned earlier is successfully implemented, the problems of parking and traffic congestion in Ikeja Central Business District will be a thing of the past. 


\section{References}

Adeniji, K. (1993). Public Transportation: a basic need in Nigeria. ITCC review, 46(1983, 92), 5-6. "Urban Development and Public Transportation in Nigeri" Third World Planning review, 4, 383 - 389.

Arnold, I. H. (1961). Transportation and Traffic Management Alexander Hamiltion Institute, New York.

Buchanma, C. (1963). Traffic in Town - Penguin, London.

Dar-Al-Hardasah. (1988). Demand for Travel. Lagos Mass Transit Option Study (pp. 74). Master Plan for Metropolitan Lagos WIBUR SMITH AND ASSOCIATES, LAGOS.

Filani, M. O., \& Osayimnes. (1979). Intra-City Traffic Flow Problems in Nigeria: The case of Ibadan Metropolitan Area. National Geographic Journal, 22(1), 17-31.

Foster, C. D. (1975). The Transport Problem Groom Helm, London Urban Passenger Transportation in Nigeria. Heinemann Education Books (Nigeria) Plc Lagos.

Odugbemi, O. O., \& Oyesiku, O. O. (2000). Research Methods in the Social and Management. Sciences Centre for Sandwich Programmes (CESAP), Ogun State University, Ago-Iwoye.

Onakomaiya, S. O. (1981). "Highway Development in Nigeria"-A Review of Policies and Programmes (1900-1980), NISER, Ibadan, Monograph series No. 5, NISEF, Ibadan.

Oyesiku, O. O. (1996). Regional Analysis of Transport Infrastructure and Social-Economic Factors of Nigeria Development Research for Development, 11(1 \&2), 12(1 \& 2), 12(1 \& 2), 112-130.

Samaila, A. G. F. (1987). The Transport Factor in Rural Resource Planning and Development in Nigeria. Journal of the Nigeria Institution of Estate Surveyor and Valuers, 11(2), 81-86.

Sella, J. (1993). "Traffic Congestion" Transport Journal of the Chartered Institute of Transport in the U. K. July - August. Pp. 12-13.

Smith, W., \& Associates. (1960). Parking Study Central Business Disstrict New of leans Louisiana, 1(1), 5-15. New Heaven Conn.

Ullman, E. L. (1956). The role of Transportation as a basis for interaction. In Thomas, W. L. (Ed.), Man'S Role in Changing the Face of the Earth.

Wilson, B. A. (1960). Do-it-Yourself parking survey structural Engineer, 5(12), 26-32. Leonard Hill Books Ltd. 